\title{
EFFICIENT ELECTROCHEMICAL AMMONIA REMOVAL SYSTEM
}

\author{
WANG, Y. ${ }^{1}-$ SONG, $\mathrm{W}^{2^{*}}-\mathrm{JI}, \mathrm{L} .{ }^{1}-\mathrm{GUO}, \mathrm{J}^{3}{ }^{3}$ - CAI, L. ${ }^{1}-$ ZHANG, Y. ${ }^{4}$ \\ ${ }^{1}$ Institute of Innovation \& Application, Zhejiang Ocean University, Zhoushan 316022, China \\ ${ }^{2}$ School of Petrochemical \& Energy Engineering, Zhejiang Ocean University \\ Zhoushan, 316022 China \\ ${ }^{3}$ College of Food and Medical, Zhejiang Ocean University, Zhoushan 316022, China \\ (phone: +86-580-255-0008; fax: +86-580-255-1319) \\ ${ }^{4}$ Metalock Engineering Ningbo Co. Ltd., Zhoushan 316022, China \\ (phone: +86-580-801-2252; fax: +86-580-801-2253) \\ *Corresponding author \\ e-mail: swd60@163.com; phone: +86-188-580-2759
}

(Received 25 $5^{\text {th }}$ May 2018; accepted $31^{\text {st }}$ Jul 2018)

\begin{abstract}
Efficient electrochemical ammonia oxidation system was studied with an objective to enhance the selectivity of ammonia to nitrogen gas and to remove the by-products in an undivided electrochemical cell, in which various cathodes $\left(\mathrm{Ti}, \mathrm{Cu} / \mathrm{Zn}, \mathrm{Fe}\right.$ ) and $\mathrm{Ti} / \mathrm{IrO}_{2}-\mathrm{Pt}$ anode were assembled. In the present study, anodic oxidation of ammonia and cathodic reduction of by-products were achieved, especially with $\mathrm{Cu} / \mathrm{Zn}$ cathode. The ammonia- $\mathrm{N}$ decreased from $100.0 \mathrm{mg} / \mathrm{L}$ to $0.0 \mathrm{mg} / \mathrm{L}$ in the presence of $1.0 \mathrm{~g} / \mathrm{L} \mathrm{NaCl}$ after $120 \mathrm{~min}$ electrolysis at the current density of $30.0 \mathrm{~mA} / \mathrm{cm}^{2}$ with $\mathrm{Cu} / \mathrm{Zn}$ cathode and $\mathrm{Ti} / \mathrm{IrO}_{2}$ anode. No nitrite was detected in the treated solutions. The concentration of chloramine was $0.24 \mathrm{mg} / \mathrm{l}$. About $97.34 \%$ of initial TN was transformed into nitrogen gas in $\mathrm{Cu} / \mathrm{Zn}$ system, indicating that $\mathrm{Cu} / \mathrm{Zn}$ cathode has better performance than $\mathrm{Ti}$ and $\mathrm{Fe}$ cathode. The results indicated that $\mathrm{Cu} / \mathrm{Zn}$ cathode exhibited a little higher reduction ability, possibly attributed by the higher electrocatalytic activity of brass containing $\mathrm{Zn}$ (35$41 \mathrm{wt} \%$ ) which significantly influenced the kinetics of current density. As ammonia could be completely removed by the simultaneous oxidation and reduction in this study, it is suitable for deep treatment of ammonia polluted water.
\end{abstract}

Keywords: water pollution, electrocatalysis, ammonia nitrogen, dimensionally stable anode, electrocatalytic activity

\section{Introduction}

Ammonia contamination in water bodies is a widespread environmental problem. Usually, two main categories of treatment processes, physicochemical and biological treatment methods, were employed for ammonia removal from domestic and industrial wastewaters, including ion exchange, air stripping, breakpoint chlorination, and biological process and so on (Rahmani et al., 2004; Du and Liu, 2005; Wang and Liu, 2006). As electrochemical oxidation of ammonia has high treatment efficiency, minimized sludge production, small area occupied and relatively low investment cost, many researchers have focused on it in decades.

The electrochemical method is widely used to remove ammonia from ammoniacontaining underground water or industrial wastewater, which contains low concentrations of organic matter and cannot be effectively treated by biological method. In the last decades, researchers have tried to improve electrochemical denitrification by different ways, such as using different electrodes, designing different electrochemical 
cells, addition of different supporting electrolytes and employing different power supply, etc.

In the past years, various electrodes such as $\mathrm{Pt}, \mathrm{Ru}, \mathrm{Ir}$, Ti, graphite, $\mathrm{Ni}$, Lead dioxide, dimension stable anode (DSA), boron-doped diamond (BDD) and bimetallic or multimetallic electrodes have been used in electrochemical oxidation (Feng, 2003; Vitse et al., 2005; Chen et al., 2007; De et al., 2009). It was shown that ammonia is effectively removed from solution while active chlorine was electrogenerated on the $\mathrm{Ti} / \mathrm{PtOx}-\mathrm{IrO}_{2}$ electrode with nitrogen gaseous being postulated to be the main by-product of ammonia electrolysis (Kapałka et al., 2010a). In general, during the electrochemical process of ammonia, nitrogen gas was the most favorable reduction product. One of the problems is the generation of nitrate, which needs to be further treated.

Although electrochemical method has been investigated and used to deal with ammonia issue, most researchers mainly focused on the anode effect on ammonia removal. However, few of them paid attention to the effect of cathode which may play an important role in the by-products $\left(\mathrm{NO}_{3}{ }^{-}-\mathrm{N}, \mathrm{NO}_{2}{ }^{-}-\mathrm{N}\right.$ and chloramines) generated during the process of electrochemical ammonia oxidation. On the other hand, some researchers found that the cathodes such as $\mathrm{Cu} / \mathrm{Zn}$ and Fe had high efficiency on nitrate and nitrite removal. Therefore, it is possible to decrease the production of side products by employing cathode with high nitrate and nitrite reduction ability.

From previous study, ammonia could be efficient removed by $\mathrm{Ti} / \mathrm{RuO}_{2}-\mathrm{Pt}$ anode via electrochemical oxidation process (Wang et al., 2012). To compare with previous studies in order to design a better treatment system and study the effects of different anodes on experimental results simultaneously.

In present study, an efficient electrochemical ammonia oxidation system was designed with various cathodes $(\mathrm{Ti}, \mathrm{Cu} / \mathrm{Zn}, \mathrm{Fe})$ and $\mathrm{Ti} / \mathrm{IrO}_{2}-\mathrm{Pt}$ anode. The effect of different cathodes on the reduction efficiency of ammonia to nitrogen gas and the formation of byproducts during the electrochemical process are studied in 2017, at Zhejiang Ocean University labs. The optimum operating conditions are also discussed, to enhance the selectivity of ammonia to nitrogen gas and to remove the by-products simultaneously.

\section{Materials and methods}

\section{Electrochemical apparatus}

The experiments are carried out in undivided cells using $\mathrm{Ti}, \mathrm{Fe}$ and $\mathrm{Cu} / \mathrm{Zn}$ plates as cathodes and $\mathrm{Ti} / \mathrm{IrO}_{2}-\mathrm{Pt}$ anode, respectively for the treatment of synthetic ammonia solution with anodic ammonia oxidation and cathodic reduction rates being compared. During the experiments, the influence of initial chloride ion concentration, current density, temperature and initial $\mathrm{pH}$ are investigated and assessed. The concentrations of ammonia, nitrite, nitrate, chloramine, and dissolved metals are determined with standard methods. The current efficiency (include the average current efficiency (ACE) and the instantaneous current efficiency (ICE), reaction kinetics, oxidation rate and one-way analysis of variance are used to analyze and assess this ammonia removal process.

The average current efficiency (ACE) and the instantaneous current efficiency (ICE) are calculated using Equations 1 and 2, respectively (Comninellis and Pulgarin, 1991; Van et al., 2004):

$$
A C E=3 F V\left[\left(N_{4}^{+}-N\right)_{0}-\left(N H_{4}^{+}-N\right)_{t}\right] / 14 I_{t}
$$




$$
I C E=3 F V\left[\left(N H_{4}^{+}-N\right)_{t}-\left(N H_{4}^{+}-N\right)_{t+\Delta t}\right] / 14 I_{\Delta t}
$$

where $\left(\mathrm{NH}_{4}{ }^{+}-\mathrm{N}\right)_{0},\left(\mathrm{NH}_{4}{ }^{+}-\mathrm{N}\right)_{\mathrm{t}}$ and $\left(\mathrm{NH}_{4}{ }^{+}-\mathrm{N}\right)_{\mathrm{t}+\Delta \mathrm{t}}$ are the concentration of $\mathrm{NH}_{4}{ }^{+}-\mathrm{N}(\mathrm{mg} / \mathrm{L})$ at times zero, $\mathrm{t}$ and $\mathrm{t}+\Delta \mathrm{t}(\mathrm{min})$, respectively, $\mathrm{I}$ is the current density $(\mathrm{A}), \mathrm{F}$ is the Faraday number $(96,485 \mathrm{C} / \mathrm{mol}), \mathrm{t}$ is the time ( $\mathrm{min}), \mathrm{V}$ is the volume of the electrolyte $(\mathrm{L}), 3$ is the number of exchanged electrons for the electrochemical oxidation of ammonia, and 14 is the molecular mass of ammonia ( $\mathrm{g} / \mathrm{mol})$.

Batch experiments were conducted in an apparatus at room temperature (about 23.0$26.0^{\circ} \mathrm{C}$ ). An undivided and unbuffered electrochemical cell was designed in our lab with a networking volume of $400.0 \mathrm{~mL}$. The $400.0 \mathrm{~mL}$ electrolysis cell was made of acryl plates with four outer spots for the electrodes assembled. Three metal plates include $\mathrm{Cu} / \mathrm{Zn}\left(\mathrm{Cu}: 62.2 \mathrm{wt} . \%\right.$; Zn: 37.8 wt.\%), Ti and Fe plates of $75.0 \mathrm{~cm}^{2}(15.0 \mathrm{~cm} \times 5.0 \mathrm{~cm})$ were used as the cathode respectively with $\mathrm{Ti} / \mathrm{IrO}_{2}-\mathrm{Pt}$ (TohoTech company, Japan) as the anode at the same area. A distance of $8.0 \mathrm{~mm}$ was set between the two electrodes. The immersed areas of the anode and cathode in the treated solution were the same and calculated as $50.0 \mathrm{~cm}^{2}$. A DC power with a voltage range of $0-50.0 \mathrm{~V}$ and current range of 0-5.0 A was employed as a power supply. Test synthetic ammonia solutions were prepared using $\left(\mathrm{NH}_{4}\right)_{2} \mathrm{SO}_{4}$ and distilled water to give a final concentration of $100.0 \mathrm{mg} / \mathrm{L}$ with no $\mathrm{Cl}^{-}$ion. In the solution, free ammonia concentration is only $0.0198 \mathrm{mg} / \mathrm{L}$. The $\mathrm{NaCl}$ dosage of $0 \mathrm{~g} / \mathrm{L}, 0.5 \mathrm{~g} / \mathrm{L}, 1.0 \mathrm{~g} / \mathrm{L}, 2.0 \mathrm{~g} / \mathrm{L}(\mathrm{w} / \mathrm{v})$ were added into the synthetic ammonia solutions to investigate the effect of influencing factors (sodium chloride dosage, current density, temperature and initial $\mathrm{pH}$ value). The current density was varied from $5.0 \mathrm{~mA} / \mathrm{cm}^{2}$ to $50.0 \mathrm{~mA} / \mathrm{cm}^{2}$, and the initial $\mathrm{pH}$ value was adjusted from 3.0 to 11.0 by $\mathrm{NaOH}(0.1 \mathrm{M})$ or $\mathrm{H}_{2} \mathrm{SO}_{4}(0.1 \mathrm{M}) .0 .5 \mathrm{~g} / \mathrm{L} \mathrm{Na}_{2} \mathrm{SO}_{4}$ was added in all solution as supporting electrolyte. At different intervals, $1.5 \mathrm{~mL}$ of sample was drawn from the electrochemical cell for analysis. The electrolysis was ceased when either $90.0 \%$ of initial ammonia was converted or $2 \mathrm{~h}$ elapsed.

\section{Analysis}

The concentrations of ammonia and nitrate were determined by spectrophotometer (DR/4000U Spectrophotometer, USA) by standard methods (Clesceri and Eaton, 1998). Nitrite was analyzed by ion chromatography (Yokogawa IC7000, AS9-HC column). Total nitrogen (T-N) was determined with a T-N, T-P autoanalyzer (Autoanalyzer 3, Bran+Luebbe). Dissolved copper and zinc contents in the filtered samples were detected using plasma emission spectrophotometer equipment (ICAP-575, Jareruasshu). Surface morphology of electrodes was characterized ex-situ by atomic force microscopy (AFM) (Digital Instruments, DimensionTM3000, USA). Mono-, di- and tri-chloramines were determined by the colorimetric DPD method (Clesceri and Eaton, 1998). All the other analyses were done according to standard methods (Clesceri and Eaton, 1998).

\section{Results and discussion}

\section{Influence of $\mathrm{NaCl}$ dosages}

In the present experiment, as $\mathrm{NaCl}$ plays an important role on not only the ammonia oxidation rate but also the formation of the by-product nitrate, the performance of electrochemical ammonia oxidation with different $\mathrm{NaCl}$ dosage was investigated. 
Figures 1 and 2 were the concentrations of ammonia-N and nitrate-N concerning time. Figure 3 was oxidation rate of ammonia with varied chloride concentration.

a

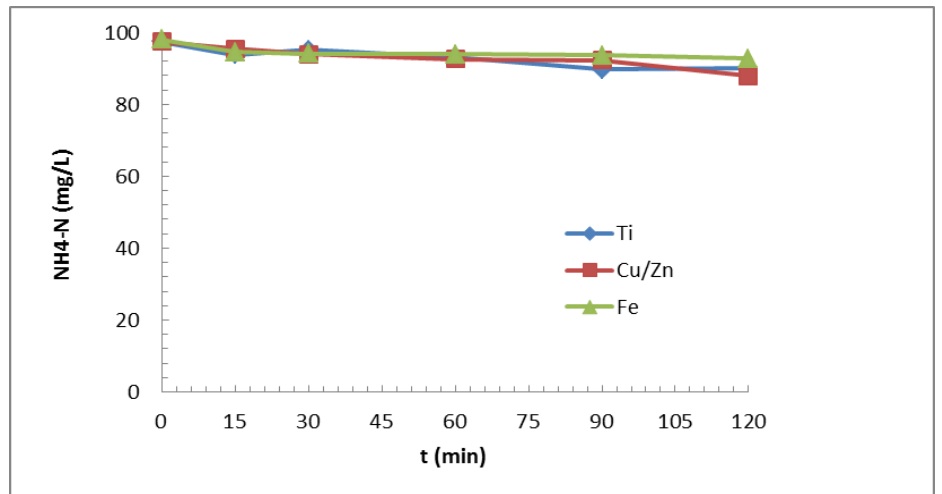

b

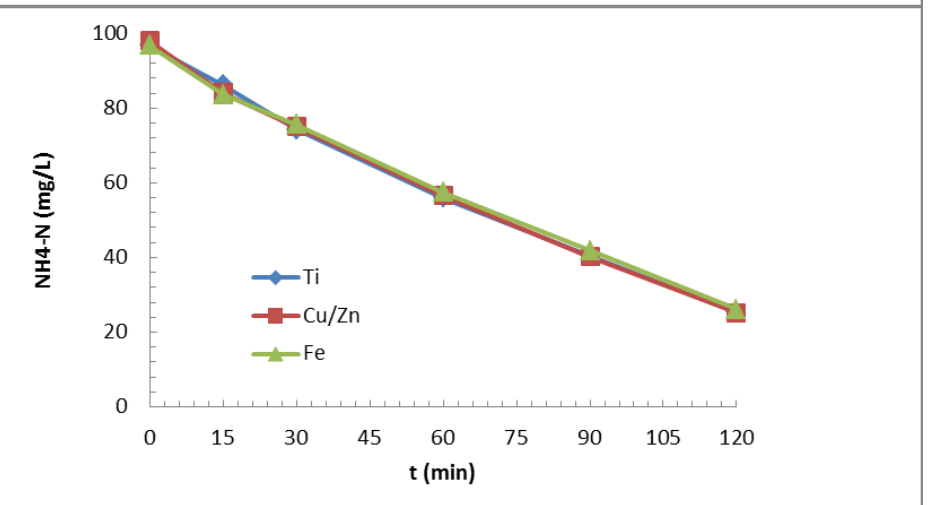

c
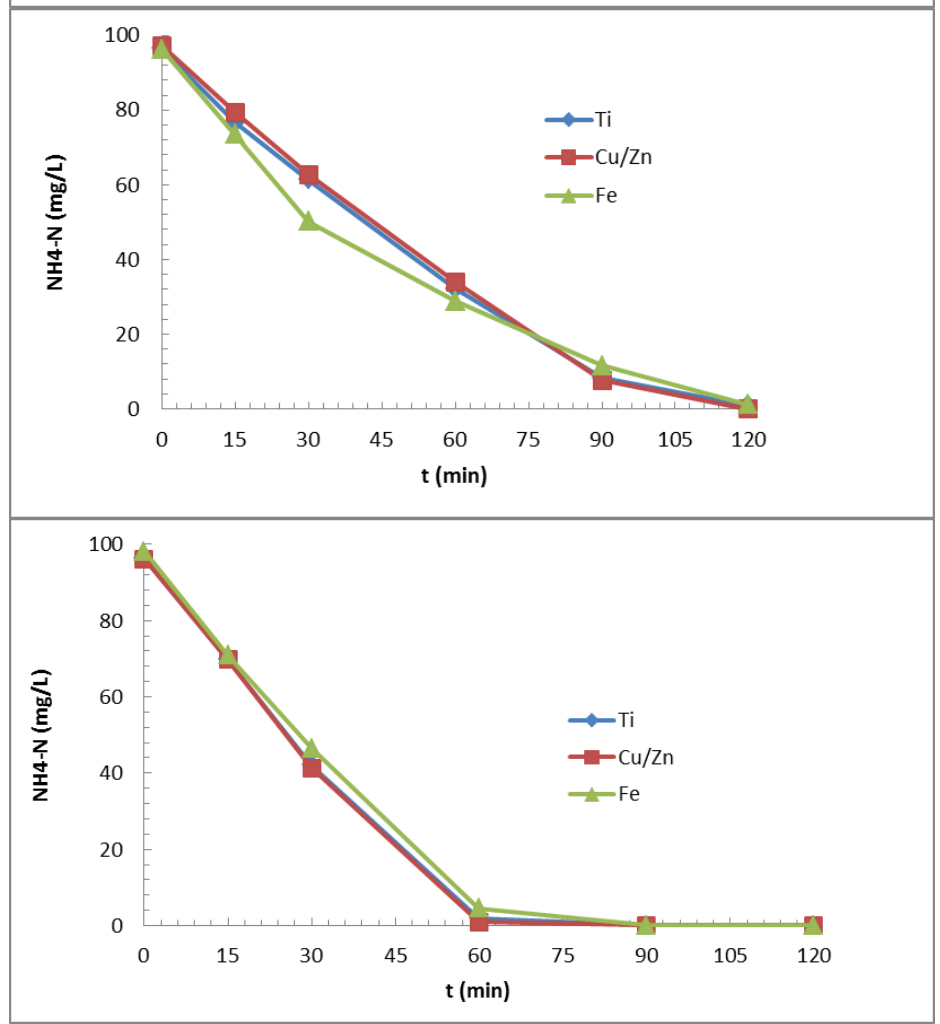

Figure 1. Concentration of ammonia with respect to reaction time. Anode: $\mathrm{Ti} / \mathrm{IrO} \mathrm{O}_{2}$-Pt, cathode:

$\mathrm{Ti}, \mathrm{Fe}, \mathrm{Cu} / \mathrm{Zn}, 30.0 \mathrm{~mA} / \mathrm{cm}^{2}$ at $0(\mathrm{a}), 0.5(\mathrm{~b}), 1.0(\mathrm{c}), 2.0(\mathrm{~d}) \mathrm{g} / \mathrm{L}$ of $\mathrm{NaCl}$, respectively 
$\mathbf{a}$

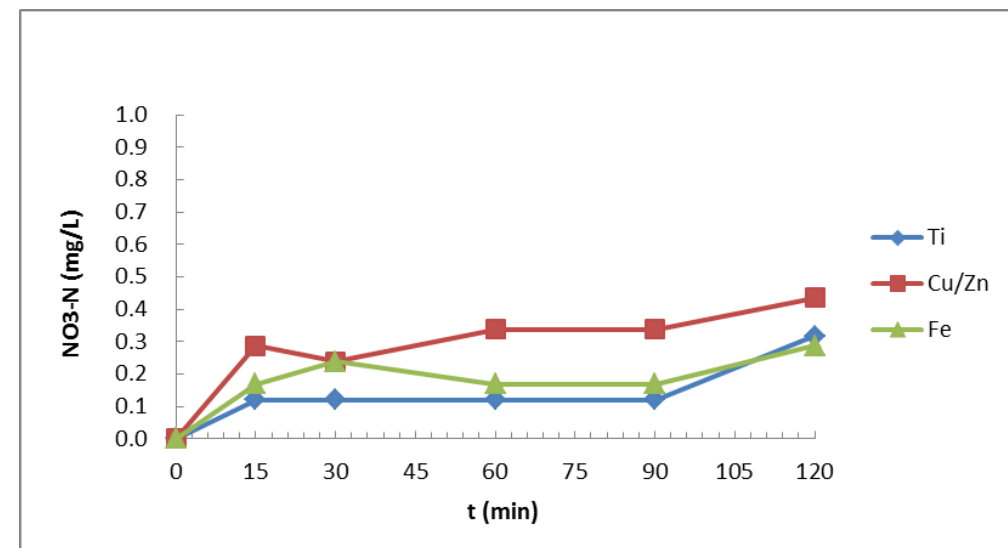

b

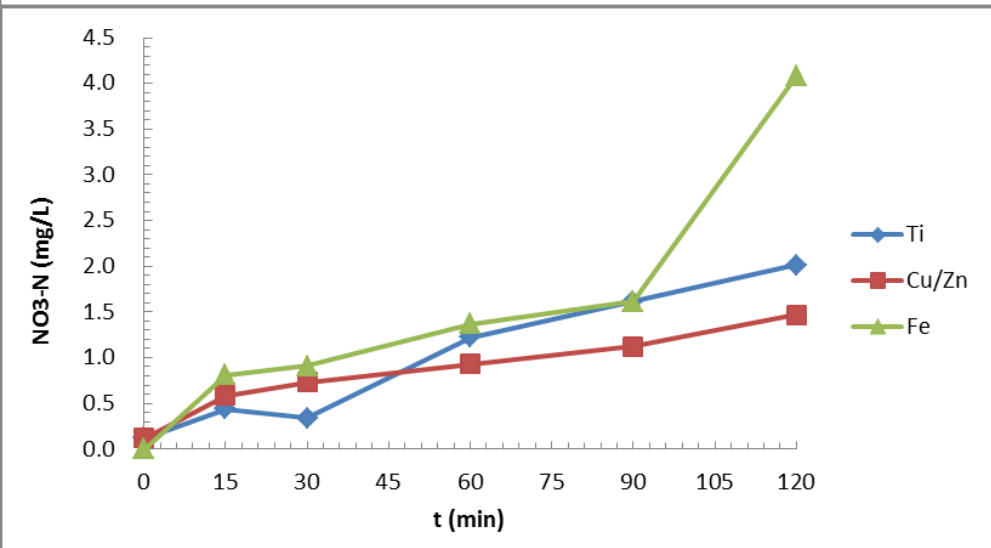

c

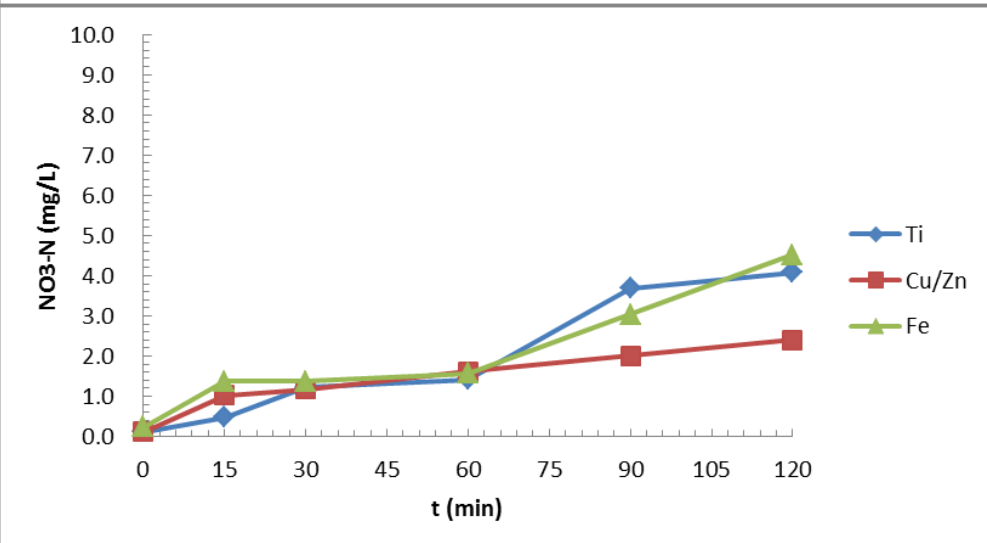

d

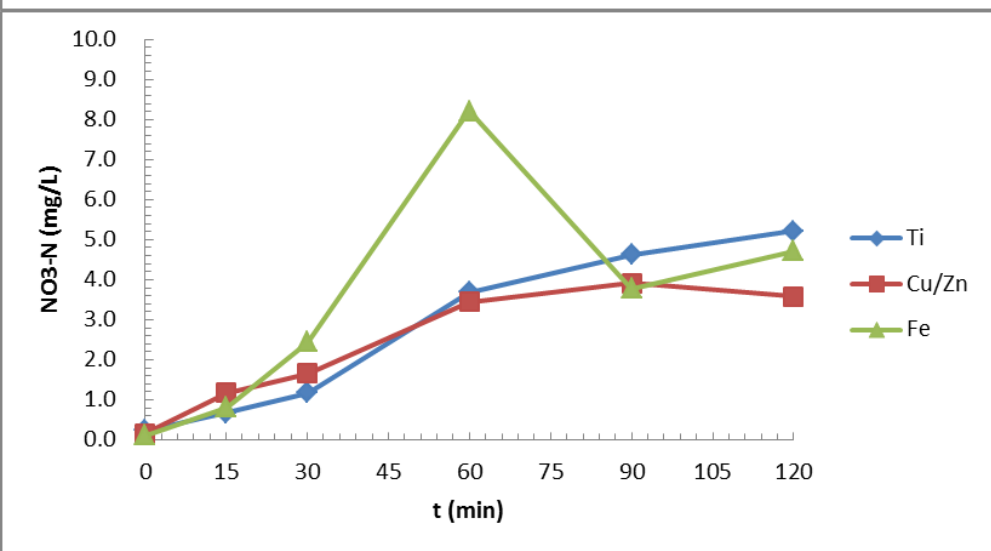

Figure 2. Concentration of nitrate with respect to reaction time. Anode: $\mathrm{Ti} / \mathrm{IrO} \mathrm{O}_{2}-\mathrm{Pt}$, cathode: $\mathrm{Ti}$, $\mathrm{Fe}, \mathrm{Cu} / \mathrm{Zn}, 30.0 \mathrm{~mA} / \mathrm{cm}^{2}$ at $\mathrm{O}(\mathrm{a}), 0.5(\mathrm{~b}), 1.0(\mathrm{c}), 2.0(\mathrm{~d}) \mathrm{g} / \mathrm{L}$ of $\mathrm{NaCl}$, respectively 


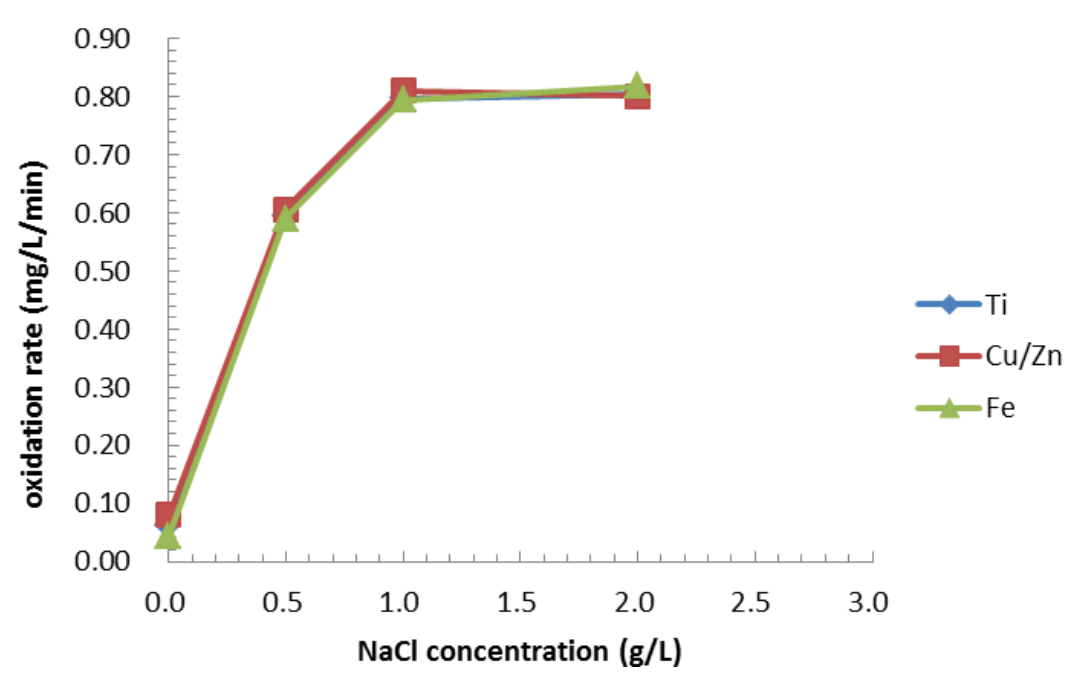

Figure 3. Influence of $\mathrm{NaCl}$ concentrations on the ammonia oxidation rate. Anode: $\mathrm{Ti} / \mathrm{IrO}-\mathrm{Pt}$, cathode: $\mathrm{Ti}, \mathrm{Fe}, \mathrm{Cu} / \mathrm{Zn}, 30.0 \mathrm{~mA} / \mathrm{cm}^{2}$, respectively

The results showed that without chloride ion, the ammonia removal efficiencies were $0.08,0.1$ and 0.05 with $\mathrm{Ti}, \mathrm{Cu} / \mathrm{Zn}$ and $\mathrm{Fe}$ as cathode employed, respectively. Meanwhile, the different amounts of nitrate formation during the electrochemical oxidation of ammonia can be attributed to the difference of the cathodes in the absence of $\mathrm{NaCl}$, in which $\mathrm{Cu} / \mathrm{Zn}$ cathode showed the lowest by-product formation. Cupro-zinc materials were well-known for their good corrosion resistance. Moreover, zinc has a good electroactivity while copper displays a good activity of electroreduction. As a result, a synergistic effect of alloying $\mathrm{Zn}$ with $\mathrm{Cu}$ could be expected. From the observed results, it can be concluded that $\mathrm{Cu} / \mathrm{Zn}$ cathode is more suitable for ammonia removal than $\mathrm{Ti}$ and $\mathrm{Fe}$ cathodes in the absence of $\mathrm{NaCl}$ because of its high selectivity for ammonia oxidation to nitrogen gas. The effect of varying $\mathrm{Cl}^{-}$concentration on ammonia-N and nitrate-N removal was also shown. The results indicated that these three cathodes exhibited almost the same performance of ammonia removal after 60 min electrolysis under $\mathrm{NaCl}$ addition. In the presence of $0.5 \mathrm{~g} / \mathrm{L} \mathrm{NaCl}$ after $120 \mathrm{~min}$ electrolysis, ammonia-N decreased from $100 \mathrm{mg} / \mathrm{L}$ to $25.4 \mathrm{mg} / \mathrm{L}, 25.3 \mathrm{mg} / \mathrm{L}$ and 26.1 $\mathrm{mg} / \mathrm{L}$ respectively with $\mathrm{Ti}, \mathrm{Cu} / \mathrm{Zn}$ and $\mathrm{Fe}$ as a cathode. It is clear that the ammonia-N was significantly decreased compared with that in the absence of $\mathrm{NaCl}$, which proved the key role of indirect oxidation during electrochemical oxidation of ammonia (Deng and Englehardt, 2007). Meanwhile, nitrate- $\mathrm{N}$ increased from 0 to $2.0 \mathrm{mg} / \mathrm{L}, 1.5 \mathrm{mg} / \mathrm{L}$ and $4.0 \mathrm{mg} / \mathrm{L}$ respectively, and no nitrite was detected through the experiments. In the presence of $1.0 \mathrm{~g} / \mathrm{L}$ and $2.0 \mathrm{~g} / \mathrm{L} \mathrm{NaCl}$, the ammonia decreased sharply, implying that in the presence of chloride ions, hypochlorite ions may be formed and then oxidize the ammonia and by-product presumably to nitrogen gas (Li et al., 2009) as listed in Equations 3-7.

For the indirect oxidation, in the presence of chloride ion, oxidizing hypochlorite ion will be formed during the electrolysis

$$
\begin{gathered}
2 \mathrm{Cl}^{-} \rightarrow \mathrm{Cl}_{2}+2 e^{-} \\
\mathrm{Cl}_{2}+\mathrm{H}_{2} \mathrm{O} \rightarrow \mathrm{HClO}+\mathrm{H}^{+}+\mathrm{Cl}^{-}
\end{gathered}
$$




$$
\mathrm{HClO} \rightarrow \mathrm{ClO}^{-}+\mathrm{H}^{+}
$$

The hypochlorite acid formed during the electrolysis would efficiently oxidize the ammonia, which is assumed to be oxidized into nitrogen gas and nitrate.

$$
\begin{gathered}
2 \mathrm{NH}_{4}^{+}+3 \mathrm{HClO} \rightarrow \mathrm{N}_{2}+3 \mathrm{H}_{2} \mathrm{O}+5 \mathrm{H}^{+}+3 \mathrm{Cl}^{-} \\
\mathrm{NH}_{4}^{+}+4 \mathrm{HClO} \rightarrow \mathrm{NO}_{3}^{-}+\mathrm{H}_{2} \mathrm{O}+6 \mathrm{H}^{+}+4 \mathrm{Cl}^{-}
\end{gathered}
$$

Stated, above $90 \%$ of removed ammonia was assumed to transform into $\mathrm{N}_{2}$ gas with $\mathrm{NaCl}$ addition, which was similar to another report (Kim et al., 2005). The production of $\mathrm{N}_{2}$ could be calculated as equal to the loss of $\mathrm{N}$ element according to the $\mathrm{N}$ conservation law (Xiao et al., 2009). Simultaneously, intermediate nitrate ions were formed in the water. On the contrary, the by-product formation had different results. The nitrate formation could come from not only the indirect oxidation of ammonia by $\mathrm{HClO}$ but also by hydroxyl radicals. The by-product formation generated by $\mathrm{Ti}$ and $\mathrm{Fe}$ increased during electrolysis while it increased for the first period and then decreased finally under $\mathrm{Cu} / \mathrm{Zn}$ cathode condition. As $\mathrm{Cu} / \mathrm{Zn}$ cathode exhibited high reduction ability, the $\mathrm{NO}_{3}{ }^{-}$concentration was the lowest. Mácová and Bouzek (2005) found that brass is containing $\mathrm{Zn}$ higher than $35 \mathrm{wt}$. \% and lower than $41 \mathrm{wt} . \%$ will significantly influence the kinetics of current density, and higher electrocatalytic activity of $\mathrm{Cu} / \mathrm{Zn}$ than both $\mathrm{Cu}$ and $\mathrm{Zn}$ was observed.

It can be concluded that ammonia oxidation rate was increased with the increased dosage of $\mathrm{NaCl}$, while nitrate formation was different with various cathodes, which suggested that the cathode and chloride ion concentration can be optimized in the ammonia solution during electrolysis process with effective ammonia removal and relatively low amount of by-products left in the solution. Therefore, the electrochemical process in the presence of chlorides showed a higher capacity and selectivity in ammonia transformation into nitrogen gas (Xiao et al., 2009) In this study, the optimum $\mathrm{NaCl}$ concentration was $1.0 \mathrm{~g} / \mathrm{L}$ and the best cathode was $\mathrm{Cu} / \mathrm{Zn}$ cathode. As the combination of $\mathrm{Ti} / \mathrm{IrO}_{2}-\mathrm{Pt}$ anode and $\mathrm{Cu} / \mathrm{Zn}$ cathode showed a good performance for ammonia oxidation, the influence of several other factors, such as current density initial $\mathrm{pH}$ and temperatures were also studied.

\section{Influence of current density}

Figure 4 shows that current density had some effect on the removal of ammonia and the nitrate-N production. In this work, current densities ranged from $5.0 \mathrm{~mA} / \mathrm{cm}^{2}$ which is the minimum required to achieve effective oxidation of ammonia (Cossu et al., 1998).

The ammonia concentration decreased from $100.0 \mathrm{mg} / \mathrm{L}$ to $80.9 \mathrm{mg} / \mathrm{L}, 59.3 \mathrm{mg} / \mathrm{L}$, $23.2 \mathrm{mg} / \mathrm{L}, 0.0 \mathrm{mg} / \mathrm{L}$ in $120 \mathrm{~min}$ respectively (Fig. 4a). This observation is in agreement with the previous report that an increase in current density improves ammonia-N treatment efficiencies under the same charge loading. The possible reason is that the increased current density during electrochemical oxidation could enhance chlorine generation, which was responsible for subsequent removal of pollutions (Deng et al., 2007).

Figure $4 b$ shows the variation of nitrate-N during electrolysis at different current densities. The final concentration of nitrate-N decreased with the increase of current 
density. The nitrate- $\mathrm{N}$ increased from 0 to $2.6 \mathrm{mg} / \mathrm{L}, 2.4 \mathrm{mg} / \mathrm{L}, 1.3 \mathrm{mg} / \mathrm{L}, 2.4 \mathrm{mg} / \mathrm{L}$, $3.3 \mathrm{mg} / \mathrm{L}$ and $2.8 \mathrm{mg} / \mathrm{L}$ in $120 \mathrm{~min}$, respectively. Ammonia oxidation rate has been reported to be linearly by current density (Vanlangendonck et al., 2005), which is in agreement with the present experiments. A similar tendency was obtained in the present experiments. At lower current density, less amount of hypochlorite acid was produced, which was not enough to oxidize all the ammonia present in the solution.

a

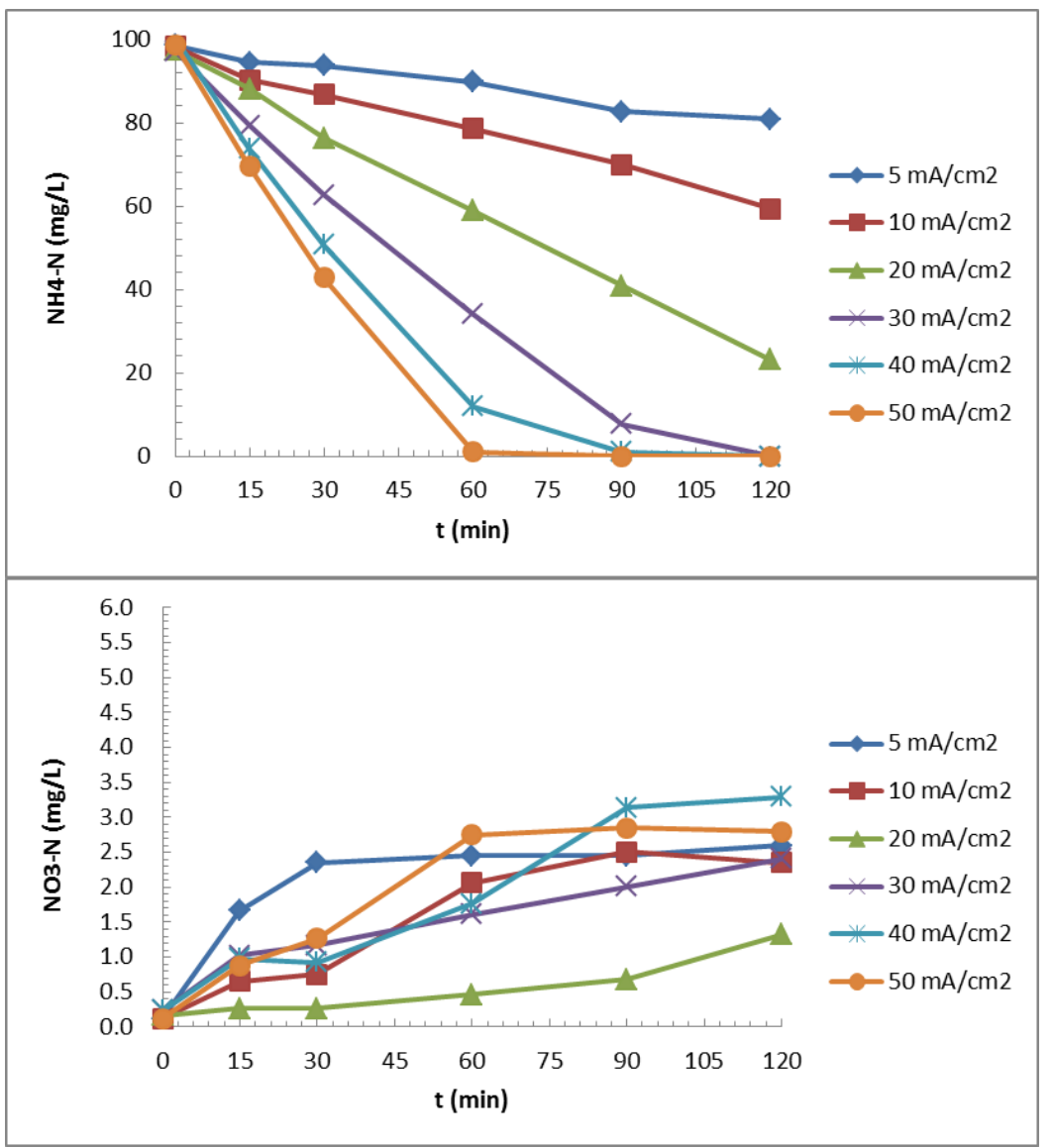

Figure 4. The concentration of ammonia (a) and nitrate (b) concerning reaction time at different current densities. Anode: $\mathrm{Ti} / \mathrm{IrO} \mathrm{H}_{2}-\mathrm{Pt}$, cathode: $\mathrm{Cu} / \mathrm{Zn}, 1.0 \mathrm{~g} / \mathrm{L} \mathrm{NaCl}$

And from Figure 5, the ammonia oxidation rate almost increased with current density increased from 5.0 to $50.0 \mathrm{~mA} / \mathrm{cm}^{2}$. This enhancement could be attributed to more chlorine generated responsibly for subsequent removal of pollutions (Deng et al., 2007).

The impact of current density on both ICE and ACE during electrolysis are also investigated (data not shown). At a higher current density, the ICE and ACE decreased rapidly as the duration of electrolysis increased. Initially, the ammonia concentration and chloride ion concentration were high, and the electrical energy was mainly consumed by the ammonia oxidation. With the electrolysis progressed the electrical energy was mainly consumed by oxygen evolution and chlorate formation, thus resulting in a decrease in current efficiency. 
Therefore, in the present experiments, to remove all of the ammonia with the consideration of ACE and ICE, the optimum current density was determined at $30.0 \mathrm{~mA} / \mathrm{cm}^{2}$.

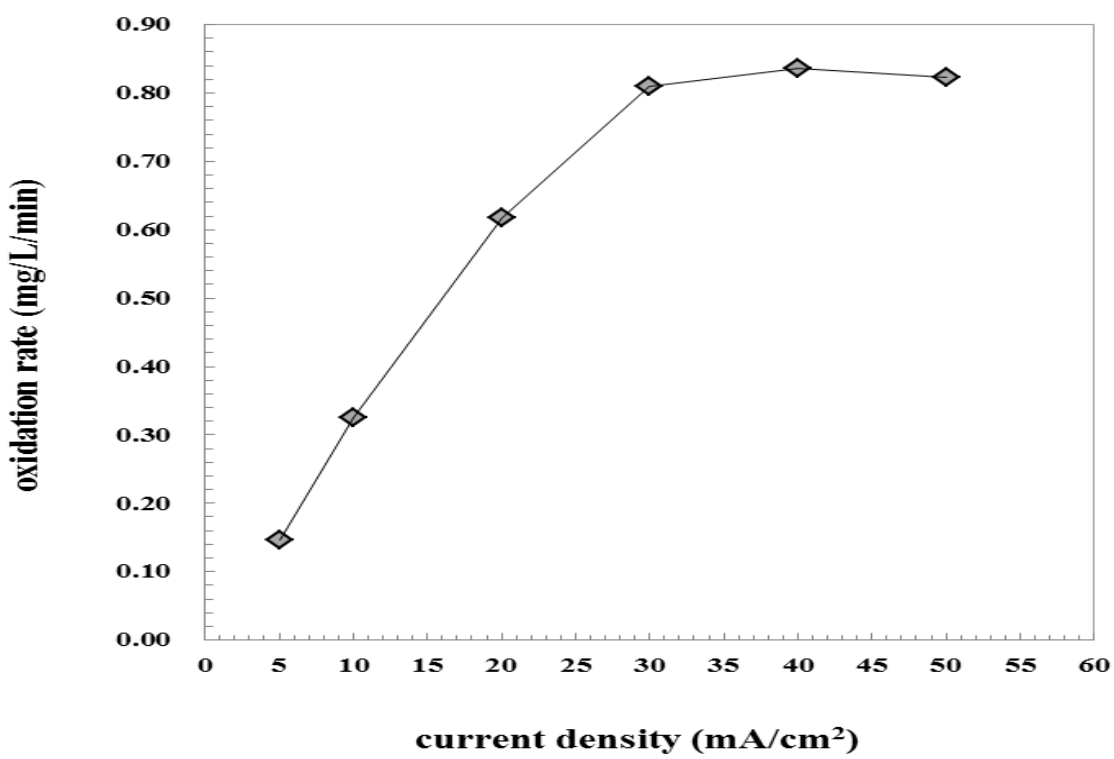

Figure 5. Effect of current density on ammonia oxidation rate under $1.0 \mathrm{~g} / \mathrm{L}$ of $\mathrm{NaCl}$ condition

\section{Influence of initial $\mathrm{pH}$}

Figures 6 and 7 present the ammonia oxidation rate under different initial $\mathrm{pH}$ conditions. Initial $\mathrm{pH}$ of 3, 5, 7, 9 and 11 were tested.

The ammonia decreased from $100.0 \mathrm{mg} / \mathrm{L}$ to $1.0 \mathrm{mg} / \mathrm{L}$ and $0 \mathrm{mg} / \mathrm{L}$ in $120 \mathrm{~min}$, respectively under initial $\mathrm{pH} 3.0,5.0,7.0,9.0$ and 11.0 conditions. The oxidation rates were almost $0.8 \mathrm{mg} / \mathrm{L} / \mathrm{min}$.

The results of one-way analysis of variance $\left(\mathrm{p}=0.991\right.$ for $\mathrm{NH}_{4}-\mathrm{N}$ and 0.541 for $\mathrm{NO}_{3}-\mathrm{N},>0.05$, data not shown) confirmed that electrochemical treatment is independent of initial $\mathrm{pH}$. This result agrees with Lin and $\mathrm{Wu}$ (Lin and $\mathrm{Wu}, 1996$ ), but different from Kapałka et al. (2010b, 2011).

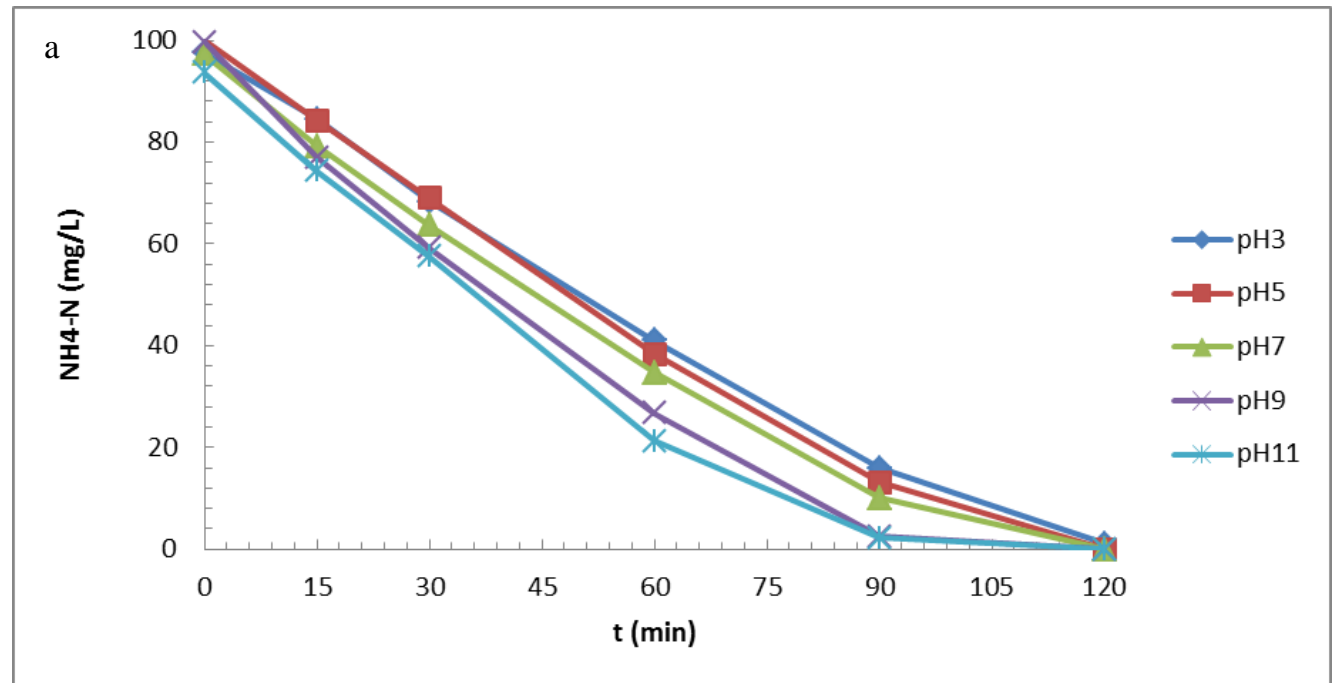




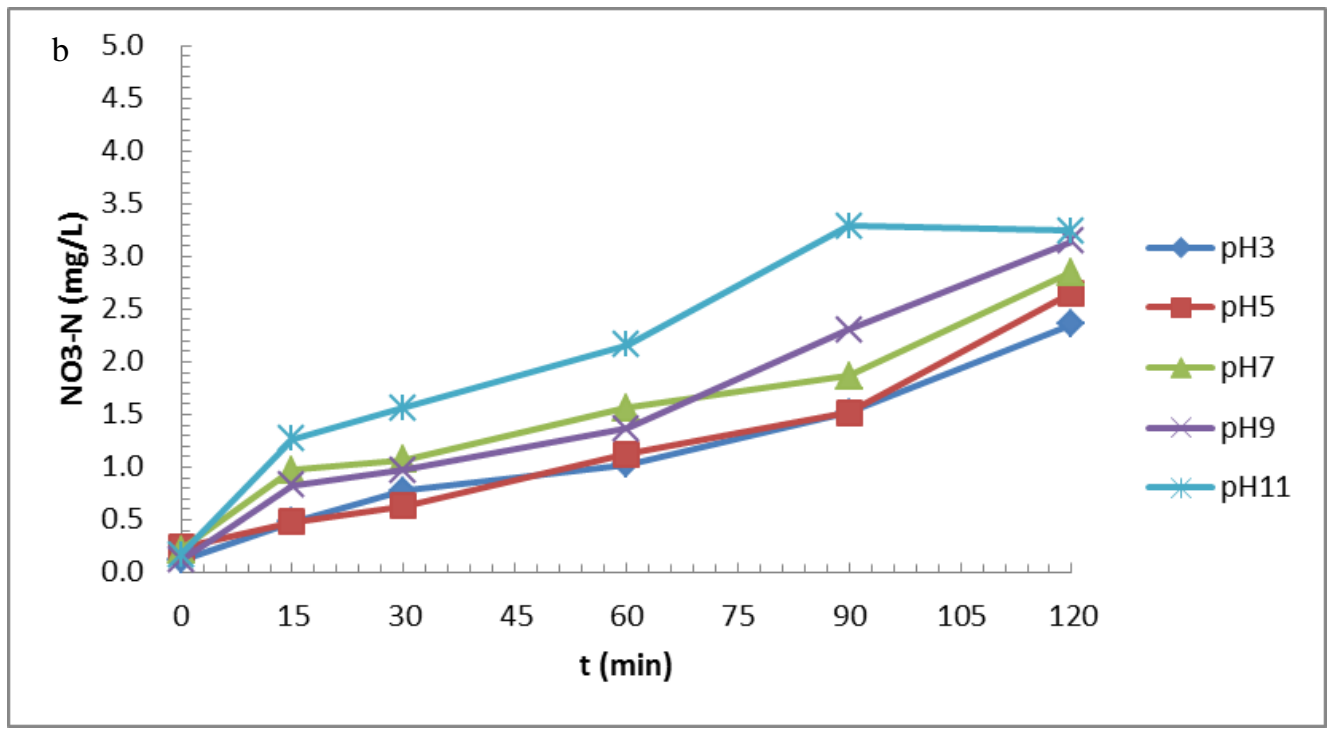

Figure 6. The concentration of ammonia (a) and nitrate (b) VS time at different initial pH. Anode: $\mathrm{Ti} / \mathrm{IrO} \mathrm{r}_{2}-\mathrm{Pt}$, cathode: $\mathrm{Cu} / \mathrm{Zn}, 1.0 \mathrm{~g} / \mathrm{L} \mathrm{NaCl}, 30.0 \mathrm{~mA} / \mathrm{cm}^{2}$

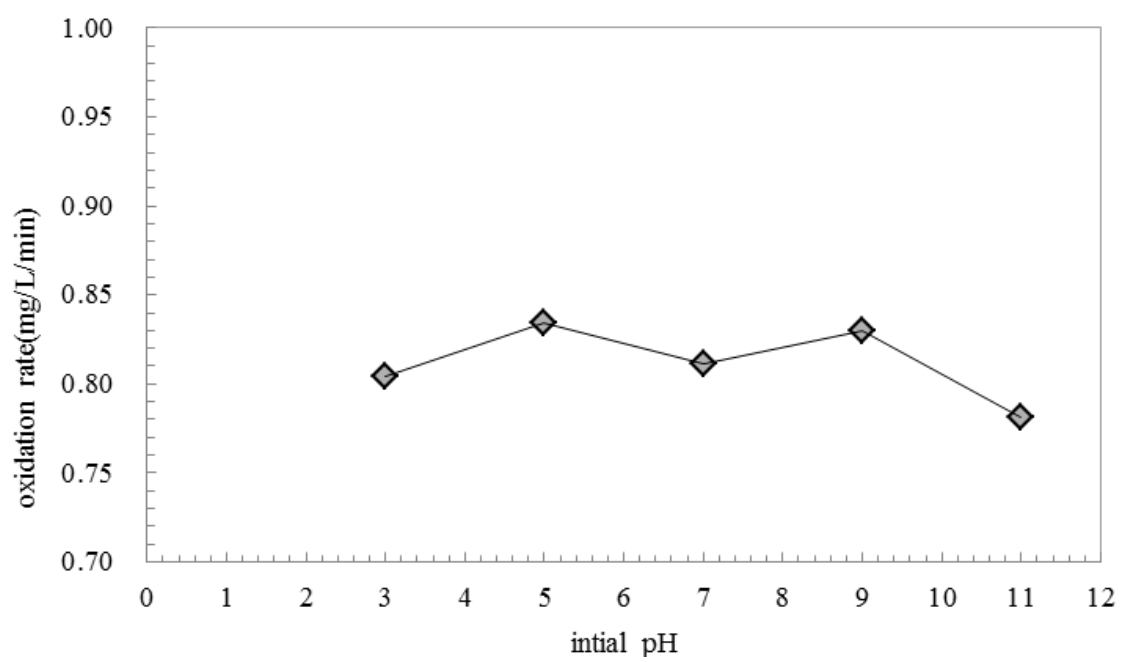

Figure 7. Electrochemical $\mathrm{NH}_{4}{ }^{+}-\mathrm{N}$ removal as a function of $\mathrm{pH}$ under a current density of 30.0 $\mathrm{mA} / \mathrm{cm}^{2}$ and $1.0 \mathrm{~g} / \mathrm{L}$ of $\mathrm{NaCl}$

Which can be explained by previously report, in a weak alkaline environment, the circulation of $\mathrm{Cl}^{-} \rightarrow \mathrm{Cl}_{2} \rightarrow \mathrm{ClO}^{-} \rightarrow \mathrm{Cl}^{-}$could be formed, making efficient use of chlorine. In a strong alkaline environment, $\mathrm{ClO}_{3}{ }^{-}$was present and competes with $\mathrm{Cl}^{-}$for electrons, decreasing the removal rate (Wang, 2000). The mechanism for the ammonia removal at anode was like the "breaking point reactions" and a stepwise process, and the reaction at cathode was hydrogen evolution reaction.

\section{Influence of temperature}

Figure 8 shows the variation of ammonia-N and nitrate-N during electrolysis at different temperature control conditions. As it was difficult to maintain high temperature throughout experiments, the temperature was only set to be at uncontrolled 
and $25.0{ }^{\circ} \mathrm{C}$. Under the uncontrolled temperature condition, the temperature of the treated solution increased from 25.0 to $41.2^{\circ} \mathrm{C}$ after 120 min electrolysis with all of the ammonia being destroyed. Under the controlled temperature $\left(25.0{ }^{\circ} \mathrm{C}\right)$ condition, ammonia oxidation was a little slower. This was mainly due to different $\mathrm{pH}$ changes in the electrolyte at different temperatures during the electrolysis (data not shown). The $\mathrm{pH}$ varied because of the various reactions occurred during ammonia oxidation process. Moreover, increasing temperature could increase the rate of diffusion and the capability of adsorption. Consequently, the ammonia oxidation rate increased when the temperature was increased from 25.0 to $41.2{ }^{\circ} \mathrm{C}$.

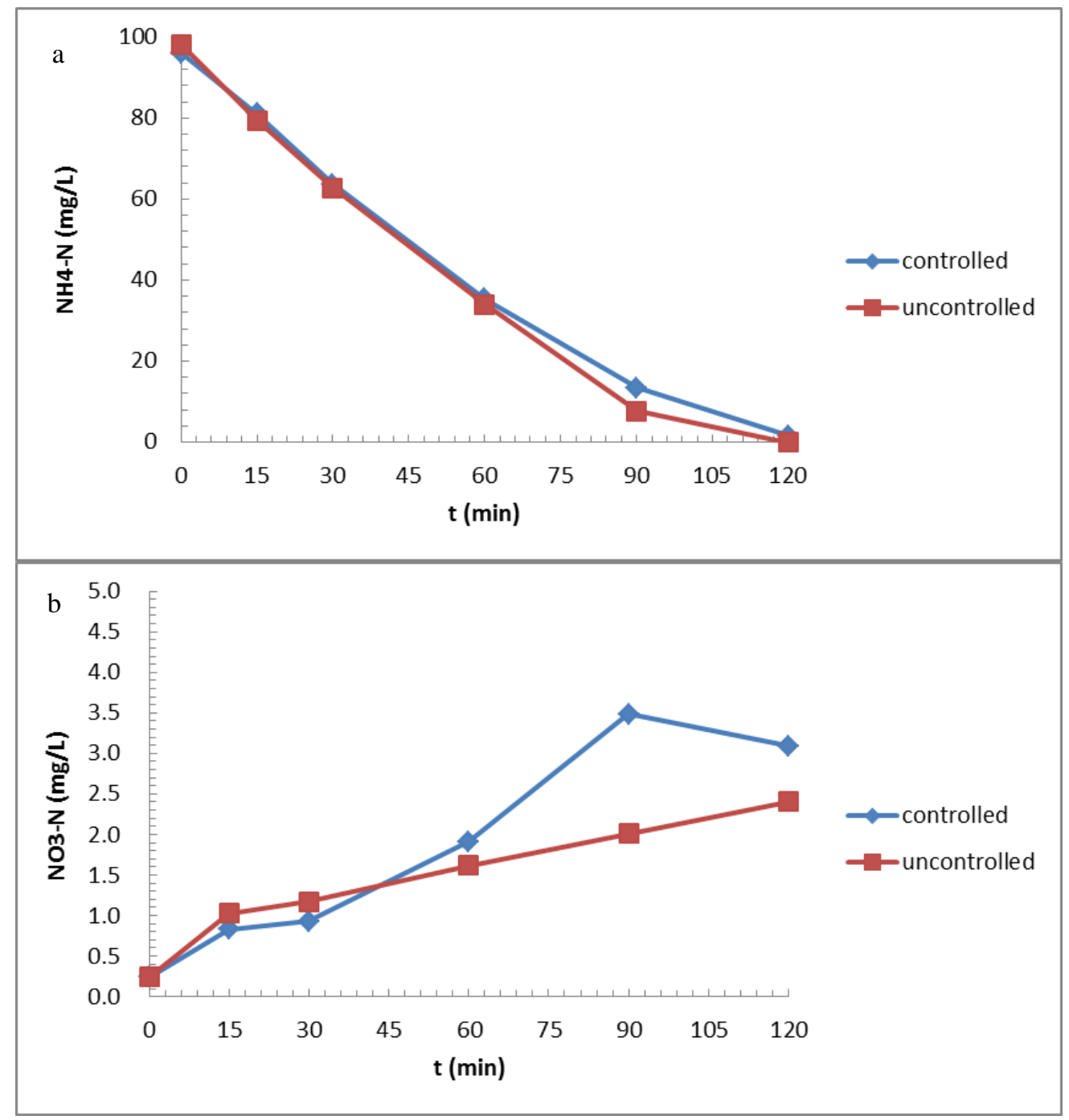

Figure 8. The concentration of ammonia (a) and nitrate (b) concerning time at temperature control methods. Anode: $\mathrm{Ti} / \mathrm{IrO} \mathrm{I}_{2}-\mathrm{Pt}$, cathode: $\mathrm{Cu} / \mathrm{Zn}, 1.0 \mathrm{~g} / \mathrm{L} \mathrm{NaCl}, 30.0 \mathrm{~mA} / \mathrm{cm}^{2}$. The final temperature of the uncontrolled condition is about $41.2{ }^{\circ} \mathrm{C}$

In addition, ammonia in aqueous solution can exist in two forms: un-ionized form $\left(\mathrm{NH}_{3}\right)$ and/or ionized form $\left(\mathrm{NH}_{4}{ }^{+}\right)$(Körner et al., 2001). Compared these two forms of ammonia, the unionized one is much easier to be oxidized. These two forms of ammonia established an equilibrium following Equation 8 (Lin and $\mathrm{Wu}, 1996$ ). 


$$
\mathrm{NH}_{3}+\mathrm{H}_{2} \mathrm{O} \leftrightarrow \mathrm{NH}_{4}^{+}+\mathrm{OH}^{-}
$$

Under the uncontrolled condition, with increasing temperature, larger amount of $\mathrm{NH}_{3}$ formed then subsequently oxidized on the electrode, which also increased ammonia oxidation rate.

The enhancement of ammonia oxidation could also be attributed to either the accelerated diffusion of ammonia from the bulk solution through the diffusive layer to the electrode surface (mass-transfer effect) or the rapid electro-oxidation reactions (activation effect).

In general, increasing temperature could enhance ammonia oxidation rate in several ways; the uncontrolled condition was a little favorable for electrochemical oxidation of ammonia.

\section{Mass balance of nitrogen}

Under the optimal condition, the mass balance of nitrogen in each treatment system is shown in Figures 9 and 10. The initial mass of ammonia nitrogen in the solution was $100 \mathrm{mg} / \mathrm{L}$. The concentrations of ammonia, nitrite, nitrate and chloramines were determined during the electrolysis as listed in Table 1. It can be seen that the ratio of ammonia transferred into nitrogen gas was the highest in $\mathrm{Cu} / \mathrm{Zn}$ cathode system, 97.34\% and the others were $94.91 \% 94.38 \%$ in Ti and Fe cathode systems, respectively. This result indicated that the activity of the $\mathrm{Cu} / \mathrm{Zn}$ electrode is relatively higher concerning the oxidation of ammonia ions and reduction of nitrate and nitrite.

Table 1. Final concentrations of $N$ species under different cathode conditions with 30.0 $\mathrm{mA} / \mathrm{cm}^{2}$ and $1.0 \mathrm{~g} / \mathrm{L} \mathrm{NaCl}$ in $120 \mathrm{~min}$

\begin{tabular}{c|c|c|c|c}
\hline Cathode & $\begin{array}{c}\text { Nitrate-N } \\
(\mathbf{m g} / \mathbf{L})\end{array}$ & $\begin{array}{c}\text { Nitrite-N } \\
(\mathbf{m g} / \mathbf{L})\end{array}$ & $\begin{array}{c}\text { Chloramine-N } \\
(\mathbf{m g} / \mathbf{L})\end{array}$ & $\begin{array}{c}\text { Ammonia-N } \\
(\mathbf{m g} / \mathbf{L})\end{array}$ \\
\hline $\mathrm{Cu} / \mathrm{Zn}$ & 2.40 & 0.00 & 0.24 & 0.00 \\
$\mathrm{Ti}$ & 4.08 & 0 & 0.24 & 0.92 \\
$\mathrm{Fe}$ & 4.52 & 0 & 0.00 & 1.16 \\
\hline
\end{tabular}

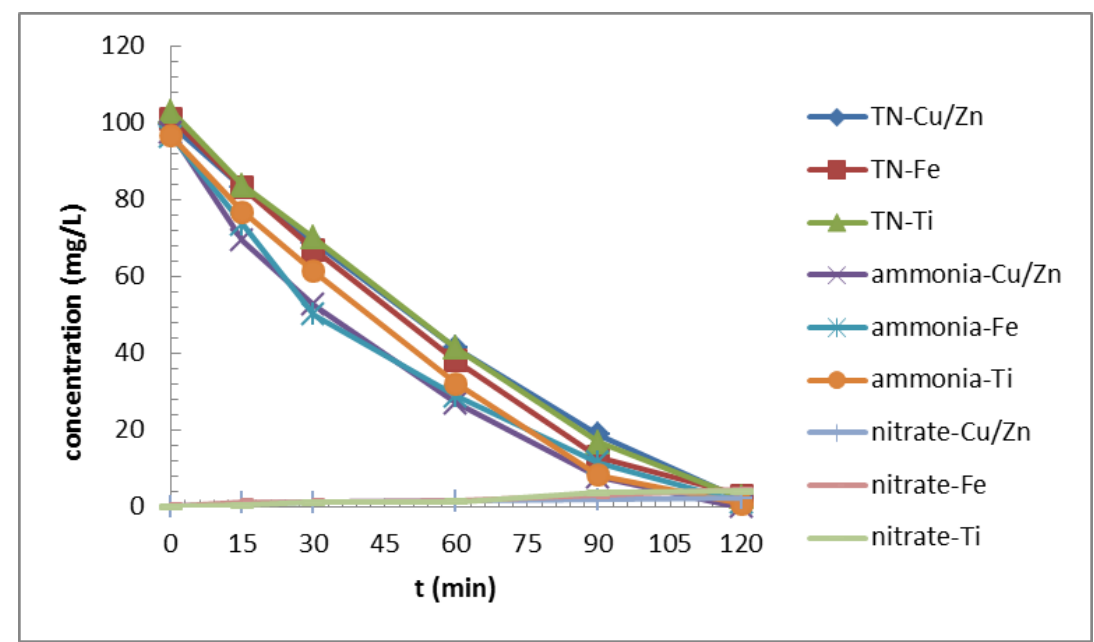

Figure 9. The concentration of TN, ammonia- $N$ and nitrate- $N$ concerning time. Anode: $\mathrm{Ti} / \mathrm{IrO} \mathrm{I}_{2}$ Pt, cathode: $\mathrm{Cu} / \mathrm{Zn}$, Ti and $\mathrm{Fe}, 1.0 \mathrm{~g} / \mathrm{L} \mathrm{NaCl}, 30.0 \mathrm{~mA} / \mathrm{cm}^{2}$ 


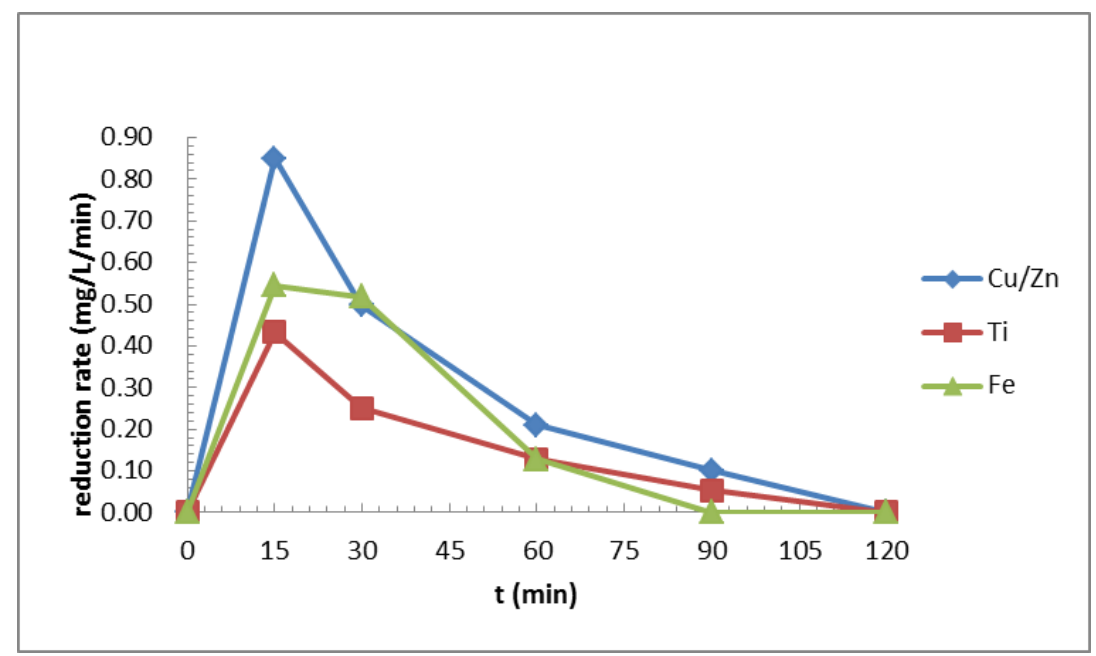

Figure 10. Reduction rate concerning time. Anode: $\mathrm{Ti}_{\mathrm{IIO}} \mathrm{O}_{2} \mathrm{Pt}$, cathode: $\mathrm{Cu} / \mathrm{Zn}$, Ti and $\mathrm{Fe}, 1.0$ $\mathrm{g} / \mathrm{L} \mathrm{NaCl}, 30.0 \mathrm{~mA} / \mathrm{cm}^{2}$

\section{Kinetic studies}

$$
\ln \left(\left[N H_{4}^{+}-N\right]_{0} /\left[N H_{4}^{+}-N\right]_{t}\right)=K_{t}
$$

where $\left[\mathrm{NH}_{4}{ }^{+}-\mathrm{N}\right]_{0}$ and $\left[\mathrm{NH}_{4}{ }^{+}-\mathrm{N}\right]_{\mathrm{t}}$ respectively correspond to the initial ammonia concentration and the concentration after a period of reaction, and $\mathrm{K}$ is the reaction rate constant.

Application of Equation 9 to the experimental data produces straight line plots as shown in Figure 11. These data can be represented by pseudo first-order kinetics. However, when the $\mathrm{NaCl}$ concentration is at low levels $(0.0 \mathrm{~g} / \mathrm{L}, 0.5 \mathrm{~g} / \mathrm{L})$, the fitness was not good, possibly caused by diffusion and consumption of $\mathrm{Cl}^{-}$ions during the electrochemical process.

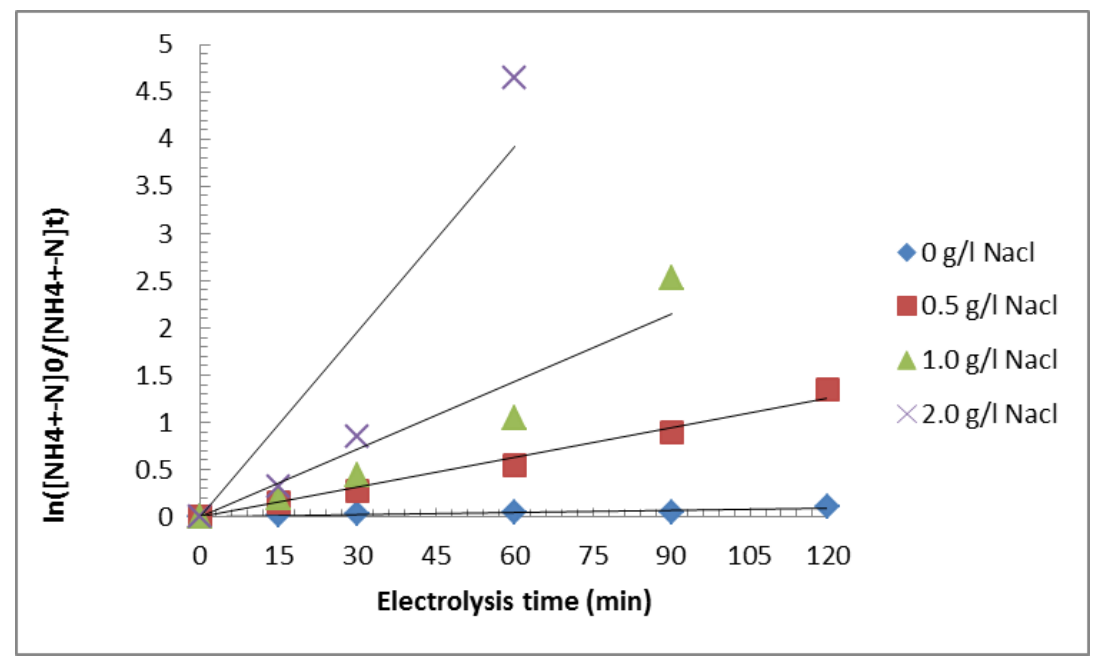

Figure 11. Pseudo-first-order kinetic model of the electrochemical treatment data, with a current density of $30.0 \mathrm{~mA} / \mathrm{cm}^{2}$ 
The kinetic rate coefficients were determined from the slopes of the straight lines under each set of operating condition (data not shown). The values of the kinetic rate coefficients obtained at different $\mathrm{NaCl}$ concentrations ranged between 0.01-0.07 $\mathrm{min}^{-1}$. Higher values of correlation coefficients $\left(\mathrm{R}^{2}=0.84-0.98\right)$ confirmed the hypothesis of the pseudo first-order reaction of ammonia oxidation. The result also indicated that ammonia could be completely removed if appropriate conditions provided.

\section{Analysis of electrode surfaces and the electrochemical solution}

Analysis of the electrolyte after electrolysis for $2 \mathrm{~h}$ at the current density of $30.0 \mathrm{~mA} / \mathrm{cm}^{2}$ revealed that the concentrations of copper and zinc in the electrolyte were less than 0.2 and $1.5 \mathrm{mg} / \mathrm{L}$, respectively, which are allowable limits for National Secondary Drinking Water Regulations (EPA 816-F-09-0004, May 2009). The low concentrations of $\mathrm{Cu}$ and $\mathrm{Zn}$ observed in the solutions may be attributed to limited corrosion of the electrodes under constant potential conditions.

As $\mathrm{Ti} / \mathrm{IrO}_{2}-\mathrm{Pt}$ anode and $\mathrm{Cu} / \mathrm{Zn}$ cathode system had the best performance for ammonia oxidation in the presence of $\mathrm{NaCl}$; the AFM investigation was carried out. The surface roughness of the anode had no change after electrolysis, implying that the $\mathrm{Ti} / \mathrm{IrO}_{2}-\mathrm{Pt}$ anode was stable for ammonia oxidation.

\section{Conclusions}

In this work, we have investigated the electrochemical ammonia removal system. To complete electrochemical oxidize of ammonia and reduce the formation of by-products, cathodic reduction of by-products, and anodic oxidation of ammonia was investigated in an undivided cell using $\mathrm{Ti} / \mathrm{IrO}_{2}$-Pt plate as an anode and three plates as a cathode for treatment of the synthetic ammonia solution respectively. It can be concluded:

(1) The ammonia- $\mathrm{N}$ decreased from $100.0 \mathrm{mg} / \mathrm{L}$ to $0.0 \mathrm{mg} / \mathrm{L}$ in the presence of $1.0 \mathrm{~g} / \mathrm{L} \mathrm{NaCl}$ after $120 \mathrm{~min}$ electrolysis at the current density of $30.0 \mathrm{~mA} / \mathrm{cm}^{2}$ with $\mathrm{Cu} / \mathrm{Zn}$ cathode and $\mathrm{Ti} / \mathrm{IrO}_{2}-\mathrm{Pt}$ anode. No nitrite was detected in the treated solutions. Dissolved copper and zinc were $0.2 \mathrm{mg} / \mathrm{l}$ and $1.5 \mathrm{mg} / \mathrm{l}$, respectively. The concentration of chloramine was $0.24 \mathrm{mg} / \mathrm{l}$. About $97.34 \%$ of initial TN was transformed into nitrogen gas in $\mathrm{Cu} / \mathrm{Zn}$ system, indicating that $\mathrm{Cu} / \mathrm{Zn}$ cathode has good performance on byproduction reduction.

(2) Initial $\mathrm{pH}$ had no obvious effect on electrochemical ammonia removal.

(3) $\mathrm{Cu} / \mathrm{Zn}$ cathode possessed the highest ammonia oxidation rate $(0.81 \mathrm{mg} / \mathrm{L} / \mathrm{min})$ and reduction rate of by-product $(0.849 \mathrm{mg} / \mathrm{L} / \mathrm{min})$. The ammonia oxidation rates with $\mathrm{Cu} / \mathrm{Zn}$ cathode was higher than that with $\mathrm{Ti}$ and $\mathrm{Fe}$ cathode. The nitrate formed during electrolysis with $\mathrm{Cu} / \mathrm{Zn}$ was the lowest than that with other cathodes. The reason why the nitrate- $\mathrm{N}$ concentration was the lowest with $\mathrm{Cu} / \mathrm{Zn}$ cathode was that because of its high reduction ability

(4) It was a little favorable for electrochemical oxidation of ammonia under uncontrolled temperature condition.

(5) The data obtained from the experiments could be represented by pseudo firstorder kinetics.

From above, the mechanism of ammonia electro-oxidation on $\mathrm{Cu} / \mathrm{Zn}$ cathode and $\mathrm{Ti} / \mathrm{IrO}_{2}-\mathrm{Pt}$ anode and formation of $\mathrm{N}_{2}$ as a final product was indicated, that ammonia is 
oxidized through several steps to various nitrogen compounds, which was in accordance with previous reports, as Equation 10.

$$
\begin{aligned}
& \mathrm{NH}_{3} \rightarrow \mathrm{NH}_{2} \mathrm{OH}_{a d s} \rightarrow \mathrm{NO}_{x} \\
& \downarrow \\
& \mathrm{N}_{2}
\end{aligned}
$$

In the present study, the ammonia was completely removed with less amount of byproducts using $\mathrm{Cu} / \mathrm{Zn}$ cathode and $\mathrm{Ti} / \mathrm{IrO}_{2}-\mathrm{Pt}$ anode electrochemical system.

Present experiments confirmed that the order of oxidation ability of those two anodes was $\mathrm{Ti} / \mathrm{IrO}_{2}-\mathrm{Pt}>\mathrm{Ti} / \mathrm{RuO}_{2}-\mathrm{Pt}$. The possible reasons are listed as follows:

(1) High oxidation ability of the $\mathrm{Ti} / \mathrm{IrO}_{2}-\mathrm{Pt}$ lead to more amounts of hydroxyl radicals and hypochlorite ion formed than at $\mathrm{Ti} / \mathrm{RuO}_{2}-\mathrm{Pt}$ anode, and they could lead to the passivation of the cathode, which resulted in the slightly lower ammonia oxidation rate.

(2) As it is likely that, the presence of $\mathrm{Cl}^{-}$ions affected the performance of each electrode. Experimental data showed that the higher oxidant generation of FAC (Free available chlorine) under $\mathrm{Ti} / \mathrm{IrO}_{2}-\mathrm{Pt}$ anode condition than the other anode was particularly observed.

(3) On the other hand, previous studies indicated that EAN (anode potential) of $\mathrm{Ti} / \mathrm{IrO}_{2}-\mathrm{Pt}$ electrode was lower and electrocatalytic activity toward chlorine evolution was higher which was confirmed by Szpyrkowicz et al. (2005).

In general, $\mathrm{Ti} / \mathrm{IrO}_{2}$-Pt anode had highest oxidation ability by various pathways, which combined with $\mathrm{Cu} / \mathrm{Zn}$ cathode exhibited good performance on ammonia oxidation that could be employed for practical use in the future.

Acknowledgements. This study was supported by the Natural Science Foundation of Zhejiang Province of China (No. LQ16D060004), Key Research and Development Projects of Zhejiang Province of China (No. 2018C02043), Demonstration Project of Marine Economic Innovation and Development of Zhoushan City of China, and Demonstration Project of Marine Economic Innovation and Development of Yantai City of China (No. YHCX-SW-L-201705).

\section{REFERENCES}

[1] Chen, J., Shi, H., Lu, J. (2007): Electrochemical treatment of ammonia in wastewater by $\mathrm{RuO}_{2}-\mathrm{IrO}_{2}-\mathrm{TiO}_{2} / \mathrm{Ti}$ electrodes. - Journal of Applied Electrochemistry 37(10): 11371144.

[2] Clesceri, L. S., Eaton, A. D. (1998): Standard Methods for the Examination of Water and Wastewater. - APHA, AWWA, WEF Publishing, Washington.

[3] Comninellis, C., Pulgarin, C. (1991): Anodic oxidation of phenol for wastewater treatment. - Journal of Applied Electrochemistry 21(8): 703-708.

[4] Cossu, R., Polcaro, A. M., Lavagnolo, M. C., Mascia, M., Palmas, S., Renoldi, F. (1998): Electrochemical treatment of landfill leachate: oxidation at $\mathrm{Ti} / \mathrm{PbO} 2$ and $\mathrm{Ti} / \mathrm{SnO} 2$ anodes. - Environmental Science and Technology 32(22): 3570-3573.

[5] De, L. R. M. G., Da, S. W. G. R., Da, C. J. W. S. D., Afonso, J. C. (2009): Removal of ammonium ion from produced waters in petroleum offshore exploitation by a batch single-stage electrolytic process. - Journal of Hazardous Materials 161(2-3): 1560-1564. 
[6] Deng, Y., Englehardt, J. D. (2007): Electrochemical oxidation for landfill leachate treatment. - Waste Management 27(3): 380-388.

[7] Du, Q., Liu, S. (2005): Ammonia removal from aqueous solution using natural Chinese clinoptilolite. - Separation and Purification Technology 44(3): 229-234.

[8] Feng, C. (2003): Development of a high performance electrochemical wastewater treatment system. - Journal of Hazardous Materials 103(1-2): 65-78.

[9] Kapałka, A., Katsaounis, A., Michels, N. L., Leonidova, A., Souentie, S., Comninellis, C., Udert, K. M. (2010a): Ammonia oxidation to nitrogen mediated by electrogenerated active chlorine on Ti/PtOx-IrO2. - Electrochemistry Communications 12(9): 1203-1205.

[10] Kapałka, A., Cally, A., Neodo, S., Comninelli, S. C., Wachter, M., Udert, K. M. (2010b): Electrochemical behavior of ammonia at $\mathrm{Ni} / \mathrm{Ni}(\mathrm{OH}) 2$ electrode. - Electrochemistry Communications 12(1): 18-21.

[11] Kapałka, A., Fierro, S., Frontistis, Z., Katsaounis, A., Neodo, S., Frey, O., De, R. N., Udert, K. M., Comninellis, C. (2011): Electrochemical oxidation of ammonia $(\mathrm{NH} 4+/ \mathrm{NH} 3)$ on thermally and electrochemically prepared $\mathrm{IrO} 2$ electrodes. Electrochimica Acta 56(3): 1361-1365.

[12] Kim, K. W., Kim, Y. J., Kim, I. T., Park, G. I., Lee, E. H. (2005): The electrolytic decomposition mechanism of ammonia to nitrogen at an $\mathrm{IrO} 2$ anode. - Electrochimica Acta 50(22): 4356-4364.

[13] Körner, S., Das, S. K., Veenstra, S., Vermaat, J. E. (2001): The effect of pH variation at the ammonium/ammonia equilibrium in wastewater and its toxicity to Lemna gibba. Aquatic Botany 71(1): 71-78.

[14] Li, M., Feng, C. P., Zhang, Z. Y., Shen, Z. L., Sugiura, N. (2009): Electrochemical reduction of nitrate using various anodes and a $\mathrm{Cu} / \mathrm{Zn}$ cathode. - Electrochemistry Communications 11(10): 1853-1856.

[15] Lin, S. H., Wu, C. L. (1996): Electrochemical removal of nitrite and ammonia for aquaculture. - Water Research 30(3): 715-721.

[16] Mácová, Z., Bonzek, K. (2005): Electrocatalytic activity of copper alloys for NO3reduction in a weakly alkaline solution Part 1: Copper-zinc. - Journal of Applied Electrochemistry 35(12): 1203-1211.

[17] Rahmani, A. R., Mahivi, A. H., Mesdaghinia, A. R., Nasseri, S. (2004): Investigation of ammonia removal from polluted waters by Clinoptilolite zeolite. - International Journal of Environment Science and Technology 1(2): 125-133.

[18] Szpyrkowicz, L., Radaelli, M., Daniele, S. (2005): Electrocatalysis of chlorine evolution on different materials and its influence on the performance of an electrochemical reactor for indirect oxidation of pollutants. - Catalysis Today 100(3-4): 425-429.

[19] Van, H. K., Verhaege, M., Verstraete, W. (2004): Electro-oxidative abatement of lowsalinity reverse osmosis membrane concentrates. - Water Research 38(6): 1550-1558.

[20] Vanlangendonck, Y., Corbisier, D., Van, L. A. (2005): Influence of operating conditions on the ammonia electro-oxidation rate in wastewaters from power plants (ELONITA ${ }^{\mathrm{TM}}$ technique). - Water Research 39(13): 3028-3034.

[21] Vitse, F., Cooper, M., Botte, G. G. (2005): On the use of ammonia electrolysis for hydrogen production. - Journal of Power Sources 142(1-2): 18-26.

[22] Wang, P., Liu, W., Fang, H. (2000): Electrochemical oxidation of ammonium-N in landfill leachate. - China Environ. Science 1: 289-291.

[23] Wang, Y., Liu, S. (2006): Ammonia removal from leachate solution using natural Chinese clinoptilolite. - Journal of Hazardous Materials 136(3): 735-740.

[24] Wang, Y. N., Guo, X., Li, J. L., Yang, Y. N., Lei, Z. F., Zhang, Z. Y. (2012): Efficient electrochemical removal of ammonia with various cathodes and $\mathrm{Ti} / \mathrm{RuO}_{2}-\mathrm{Pt}$ anode. Open Journal of Applied Sciences 2: 241-247.

[25] Xiao, S., Qu, J., Zhao, X., Liu, H., Wan, D. (2009): Electrochemical process combined with UV light irradiation for synergistic degradation of ammonia in chloride-containing solutions. - Water Research 43(5): 1432-1440. 